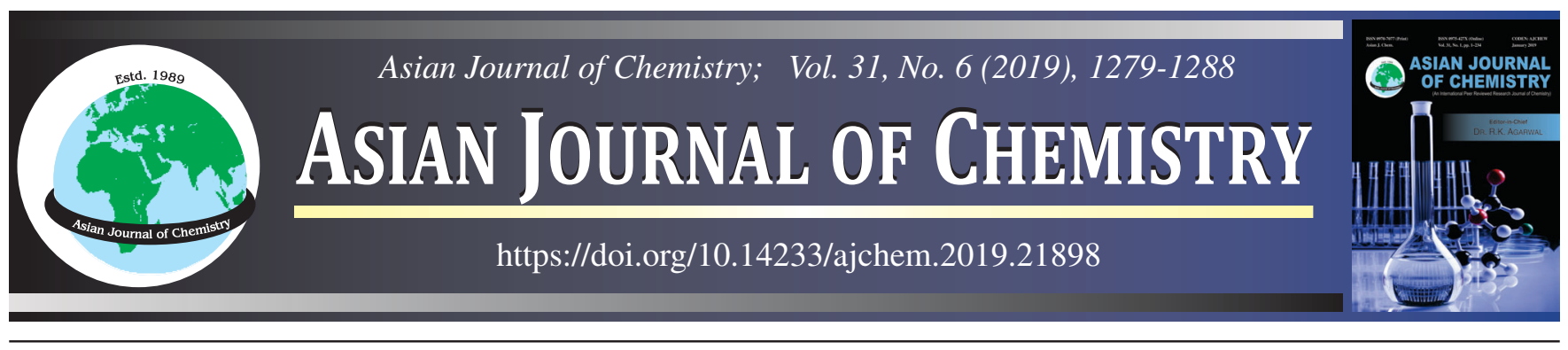

\title{
Volatile Variability and Antioxidant Activity of Rosmarinus officinalis Essential Oil as Affected by Elevation Gradient and Vegetal Associations
}

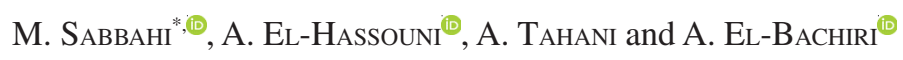

Laboratory of Physical Chemistry of the Natural Resources and Environment, University Mohammed Premier, BP 717, 60000 Oujda, Morocco

*Corresponding author: Tel: +212 652859282; E-mail: sabbahimonsif@gmail.com

Received: 26 December 2018;

Accepted: 8 February 2019;

Published online: 29 April 2019;

AJC-19369

\begin{abstract}
The essential oil yield, volatile profile and antioxidant activity, of 37 samples collected from the Rosmarinus officinalis shrubs growing wild in the different ecosystems of the provinces of Taourirt and Jerada (Oriental region in the east of Morocco), were studied in order to determine the effect of the habitat and how the vegetal associations are influencing the volatile variability of their essential oil. The essential oil compositions were determined by gas chromatography-mass spectrometry (GC-MS). The yield of the essential oil extraction ranged from 1.09 to $2.81 \%$. The major components found were 1.8-cineol (37.71-65.02 \%), camphor (6.09-27.49 \%), $\alpha$-pinene (3.08$9.98 \%)$ and $\beta$-pinene (2.83-11.7\%). The interpretation of these results revealed that the variability is attributed to varieties and genetic background rather than the ecosystems. The antioxidant activity was determined by 1,1-diphenyl-1-picrylhydrazyl (DPPH) assay which revealed a strong radical scavenging capacity for all the samples with some variability which can be explained by the variability of the content of monoterpenes oxygenated.
\end{abstract}

Key

Keywords: Rosmarinus officinalis, Essential oil, Antioxidant activity, Gas chromatography, Oriental, Morocco.

\section{INTRODUCTION}

Morocco is a Mediterranean country with wide ranging ecological conditions. As a result its land offers a rich biodiversity with more than 4200 species of plants. About 800 of these flora have an aromatic and therapeutic virtues and known as medicinal and aromatic plants [1]. Rosemary, Rosmarinus officinalis, which belongs to the Lamiaceae family, is deemed the most used aromatic and medicinal plant worldwide [2]. It's an evergreen shrub with needle like leaves and grows spontaneously especially in the western part of the Mediterranean basin [3,4]. In Morocco, rosemary is found in various regions. It grows wild, especially in the eastern parts of the country $[1,5]$. It's used in folk medicine and as a culinary additive since antiquity [6,7]. Those benefits are especially due to its essential oil, which are volatile compounds synthesized by aromatic plants as secondary metabolism [8].

The essential oil volatile composition of the Rosmarinus officinalis has been the focus of numerous researches in the recent years. It contains mainly monoterpenes and monoterpene derivatives $(95-98 \%)$, the rest is sesquiterpenes $[9,10]$.
The principal volatile compounds in rosemary essential oil are camphor, 1,8-cineol, borneol, verbenone, $\alpha$-pinene and camphene [11-13].

Those diverse components of the essential oil, are the responsible of various antimicrobial, antiviral and antioxidant activities [14-16].

The latest research over rosemary essential oil has mainly put the emphasis on its antibacterial [17-19], antifungal [9,20], insecticidal [21], anticancer [22], anti-inflammatory [23], anticorrosion of steel [24] and antioxidant properties [25,26]. This last one is considered very crucial against oxidant molecules because antioxidants act as free radical scavengers and minimize the impact of oxidative damage; as a result, they can alleviate oxidative stress, which causes a considerable damage to biological molecules $[27,28]$. Furthermore, these antioxidants are used as food preservator [26].

However, essential oil from wild populations of rosemary shows high variation concerning its composition, antimicrobial and antioxidant activities [12,14]. Various factors are influencing the composition and the effectiveness of those activities, likewise the place of origin and genetics [29], bioclimatic

This is an open access journal, and articles are distributed under the terms of the Creative Commons Attribution-NonCommercial-ShareAlike 4.0 (CC BY-NC-SA 4.0) International License which allows readers to freely read, download, copy, distribute, print, search, or link to the full texts of its articles and to use them for any other lawful non-commercial purpose as long as the original source is duly acknowledged. 
conditions [30], the phenological stage [31], the method of extraction [32] and the drying time and method [10,11]. This variability has pushed many authors to classify the essential oil composition to different chemotypes. For instance, Napoli et al. [33] demonstrate that Sicilian rosemary essential oil can be classified into three chemotypes: cineoliferum (high content in 1,8-cineol); camphoriferum (camphor $>20 \%$ ); and verbenoniferum (verbenone $>15 \%$ ).

Oriental region in Morocco (Fig. 1), which is our study area; is a large region with an area of $82820 \mathrm{Km}^{2}$, located in the northeast of the country, it's bordered at the east and the south with Algeria, the north the Mediterranean coastline; and by the desert in the south. The Mediterranean climate in the north of the region becomes more arid and continental to the south. Those ecological conditions impact the vegetal cover and offer the adequate area to rosemary to grow spontaneously. Thus, Rosmarinus officinalis covers 450000 ha of shrubs and it is spread along the mountains of the horst in the provinces of Jerada, Taourirt and Figuig, growing from sea level to 2000 meters of altitude through different ecosystems. Rosemary take an important role for the local economy since it's harvested and exploited by local cooperatives. Nevertheless, this plant is subject to excessive human exploitation and traditional valorization [34].

Knowing the importance of this plant in medical and food industry and the impact of this plant in the local economy of Oriental region and to understand the factors impacting the chemical composition, this work aims to study the relationship between the vegetal association and the chemical composition and the antioxidant activity of rosemary's essential oil. Another objective is to study the variability of rosemary's essential oil in detailed scale to have a clear vision on how the chemical composition varies through the different factors. Furthermore, this study opts for the characterization of the essential oil chemical profiling of Rosmarinus officinalis in the region which will represent an added value to the rosemary essential oil of the region as a commercial product.

\section{EXPERIMENTAL}

Total of 37 samples of Rosmarinus officinalis were collected from 37 wild populations belonging to different ecosystems of the provinces of Jerada and Taourirt in the Oriental (Eastern region of Morocco) (Fig. 1). All the samples are identified by the Forest Management and Studies Service of the Oriental region. The collection was processed in the beginning of the May 2017 at blooming stage. The collection was processed in five forests in the two provinces: Ben Yâala (Province of Jerada); and El Ayat, Nerguechoum, Lamkam, Debdou (Province of Taourirt). The sampling was based upon the altitude, longitude and the vegetal associations (the main tree or the vegetal specie) that characterize the ecosystem where rosemary shrub grows, which are: Tetraclinisarticulata, Quercusrotundifolia and Steppatenacissima. Before essential oil extraction, the plant

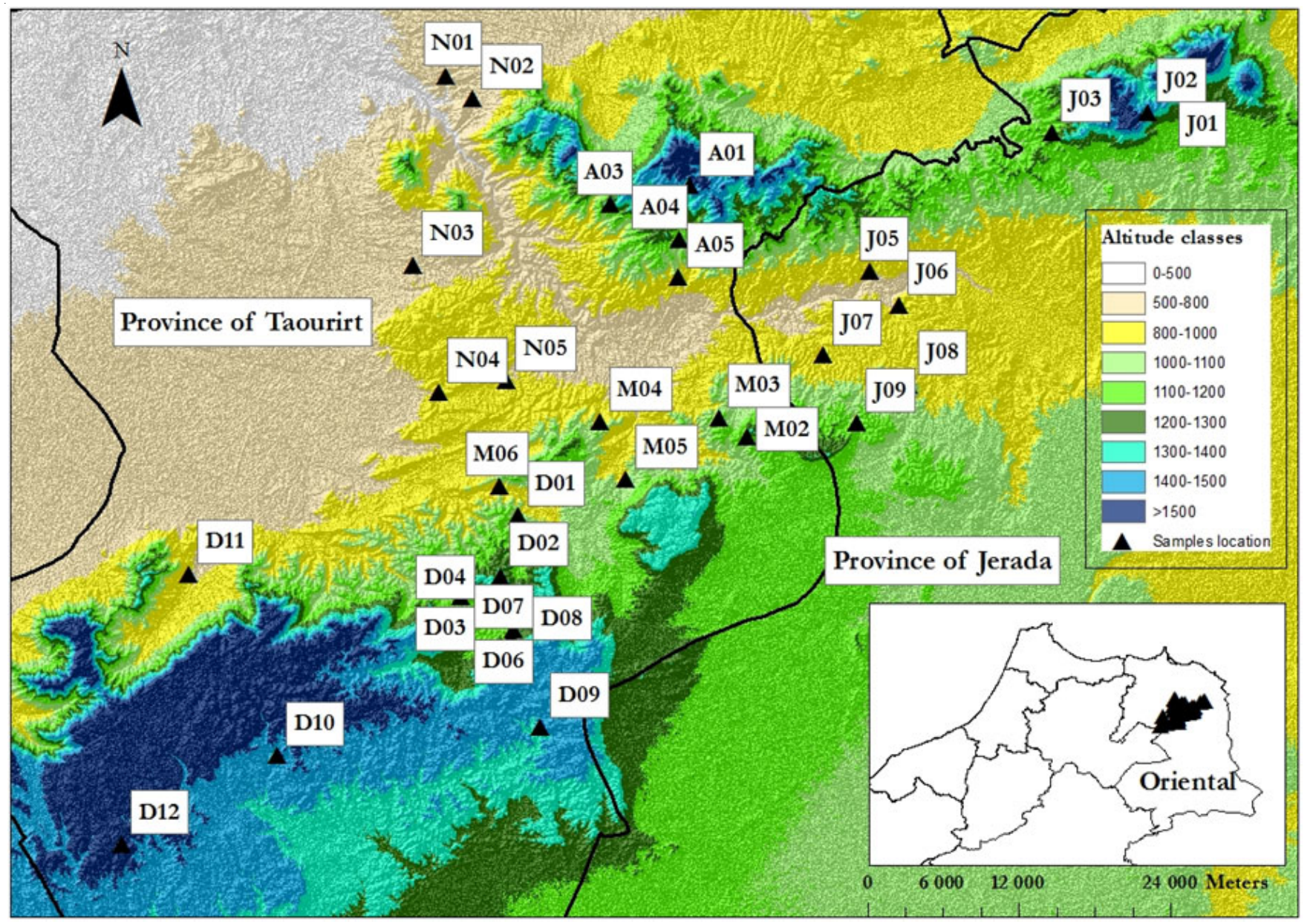

Fig. 1. Map of samples' location in the Oriental region (Provinces of Taourirt and Jerada) according to altitude classes 
material was dried at room condition $\left(25^{\circ} \mathrm{C}\right)$ for 7 days. All information concerning the 37 samples are summarized in Table-1.

Essential oil extraction: The leaves of rosemary samples were subjected to hydrodistillation for $3 \mathrm{~h}$ using a Clevengertype apparatus according to the European Pharmacopoeia (1996). The oil obtained was separated from water and dried over anhydrous sodium sulphate and kept in amber vials at 4 ${ }^{\circ} \mathrm{C}$ until chromatographic analysis. Yield percentage was calculated as volume $(\mathrm{mL})$ of essential oil per $100 \mathrm{~g}$ of plant dry matter.

Chromatography-mass spectrometry analysis: The oil was analyzed by gas chromatography-mass spectrometry (GCMS) using a Hewlett Packard 6890 mass selective detector coupled with a Hewlett Packard 6890 gas chromatograph equipped with a $30 \mathrm{~m} \times 0.25 \mathrm{~mm}$ HP-5 (cross-linked phynelmethyl siloxane) column with $0.25 \mu \mathrm{m}$ film thickness (Agilent). The injection was done manually using splitless mode, helium was used as carrier gas and the flow through the column was $1.4 \mathrm{~mL} \mathrm{~min}^{-1}$. The column was of $10^{\circ} \mathrm{C} \mathrm{min}^{-1}$ and finally raised from 230 to 280 at rate of $30^{\circ} \mathrm{C} \mathrm{min}^{-1}$. The mass spectrometry (MS) operating parameters were as follows: ionization potential, $70 \mathrm{eV}$; ionization current, $2 \mathrm{~A}$; ion source temperature, $200{ }^{\circ} \mathrm{C}$, resolution, 1000 . Mass unit were monitored from 30 to $450 \mathrm{~m} / \mathrm{z}$. Identification of components in the oil was based on matching the retention time and kovat's index relatives to $n$-alkanes, with the WILEY 275 Library as well as by comparison of the fragmentation patterns of mass spectra with those reported in the literature [35].

DPPH radical scavenging capacity (RSC): The scavenging activity of the stable 1,1-diphenyl-2-picrylhydrazyl (DPPH) free radical, was determined by the method described by Kumar et al. [36] with some modifications. The method is based on the reduction of the stable free radical DPPH in the presence of a hydrogen-donating antioxidant and the formation of the non-radical form DPPH-H as a result of the reaction. This

\begin{tabular}{|c|c|c|c|c|c|c|}
\hline \multirow{3}{*}{ Sample } & \multicolumn{6}{|c|}{$\begin{array}{l}\text { TABLE-1 } \\
\text { LAMBERT COORDINATES, ALTITUDE, LOCATION NAME, THE FOREST NAME AND VEGETAL SPECIES } \\
\text { CHARACTERIZING THE ECOSYSTEM RELATED TO SAMPLES OF WILD ROSEMARY POPULATIONS } \\
\text { COLLECTED IN } 2017 \text { FROM THE FORESTS OF THE PROVINCES OF TAOURIRT AND JERADA, MOROCCO }\end{array}$} \\
\hline & \multirow{2}{*}{ Location } & \multirow{2}{*}{ Forest } & \multicolumn{2}{|c|}{ UTM coordinates } & \multirow{2}{*}{ Altitude (m) } & \multirow{2}{*}{ Vegetal species $^{\mathrm{a}}$} \\
\hline & & & $\mathrm{X}$ & $\mathrm{Y}$ & & \\
\hline A01 & Tnezart & Ayate & 761024 & 415381 & 1434 & Quercus R. \\
\hline $\mathrm{A} 02$ & Ayate & Ayate & 758360 & 413355 & 1217 & Quercus R. \\
\hline A03 & Sidi Belkacemazaroual & Ayate & 754707 & 413898 & 1228 & Quercus R. \\
\hline A04 & Dadda Ali & Ayate & 760157 & 411155 & 1038 & Tetraclinis A. \\
\hline A05 & Baouess & Ayate & 760057 & 408187 & 920 & Tetraclinis A. \\
\hline N01 & Talmest 1 & Nerguechoum & 741652 & 424062 & 526 & Tetraclinis A. \\
\hline N02 & Talmest & Nerguechoum & 743750 & 422253 & 615 & Tetraclinis A. \\
\hline N03 & Ousraf & Nerguechoum & 739033 & 409099 & 735 & Steppa T. \\
\hline N04 & Beni Chbel & Nerguechoum & 741035 & 399103 & 819 & Pure \\
\hline N05 & Beni Chbel 2 & Nerguechoum & 746425 & 400038 & 822 & Pure \\
\hline M01 & Sidi Smail & Mkam & 768789 & 395261 & 1193 & Steppa T. \\
\hline M02 & Taida 2 & Mkam & 765518 & 395628 & 1133 & Tetraclinis A. \\
\hline M03 & Taida & Mkam & 763260 & 397112 & 1126 & Tetraclinis A. \\
\hline M04 & Ioussidene & Mkam & 753886 & 396803 & 950 & Tetraclinis A. \\
\hline M05 & Mkam & Mkam & 755927 & 392275 & 1040 & Steppa T. \\
\hline M06 & Sfia & Mkam & 745886 & 391707 & 935 & Tetraclinis A. \\
\hline D01 & Lamsadak & Debdou & 747379 & 389388 & 1012 & Quercus R. \\
\hline D02 & Zamtat & Debdou & 745986 & 384610 & 1313 & Quercus R. \\
\hline D03 & Beni Mâala & Debdou & 742855 & 382979 & 1123 & Tetraclinis A. \\
\hline D04 & Wizaght & Debdou & 744108 & 382000 & 1111 & Quercus R. \\
\hline D05 & Garage & Debdou & 749950 & 380628 & 1404 & Quercus R. \\
\hline D06 & Zoubia 2 & Debdou & 747050 & 380381 & 1205 & Quercus R. \\
\hline D07 & Zoubia & Debdou & 746808 & 379670 & 1261 & Steppa T. \\
\hline D08 & Boukraker & Debdou & 747802 & 378767 & 1487 & Quercus R. \\
\hline D09 & AiounDehaguna & Debdou & 749143 & 372720 & 1429 & Quercus R. \\
\hline D10 & LallaMimouna & Debdou & 728294 & 370460 & 1476 & Quercus R. \\
\hline D11 & Flouch & Debdou & 721221 & 384799 & 827 & Tetraclinis A. \\
\hline D12 & El Ateuf & Debdou & 715974 & 363462 & 1567 & Quercus R. \\
\hline J01 & JbelKeltoum & Béni Yaala & 799023 & 422724 & 1451 & Quercus R. \\
\hline J02 & Sidi Belkacem & Béni Yaala & 797289 & 421185 & 1400 & Quercus R. \\
\hline $\mathrm{J} 03$ & Khtitila & Béni Yaala & 789698 & 419616 & 1182 & Steppa T. \\
\hline J04 & Gafait 2 & Béni Yaala & 779778 & 408971 & 804 & Pure \\
\hline $\mathrm{J} 05$ & Gafait & Béni Yaala & 775274 & 408674 & 825 & Pure \\
\hline J06 & Wizghad & Béni Yaala & 777527 & 406002 & 820 & Steppa T. \\
\hline J07 & Tifirassine & Béni Yaala & 771589 & 402061 & 905 & Tetraclinis A. \\
\hline J08 & TiziGuezmane & Béni Yaala & 778345 & 399708 & 1017 & Quercus R. \\
\hline J09 & Loukto & Béni Yaala & 774231 & 396717 & 1039 & Steppa T. \\
\hline
\end{tabular}

${ }^{a}$ Vegetal species associated to the rosemary ecosystem: Quercus R. (Quercus rotundifolia); Tetraclinis A (Tetraclinis articulata); Steppa T. (Steppa tenacissima); pure (there is just rosemary). 
reduction can be monitored at $517 \mathrm{~nm}$ by measuring the bleaching of DPPH (violet) to DPPH-H (yellow). $0.6 \mathrm{~mL}$ of various concentration $(50,100,150$ and $200 \mu \mathrm{L} / \mathrm{mL})$ of the sample were mixed with $2.4 \mathrm{~mL}$ of DPPH in methanol diluted at 0.004 $\%$, incubated afterwards $30 \mathrm{~min}$ in dark at room temperature. Finally, we measured the absorbance at $517 \mathrm{~nm}$. Methanol and acid ascorbic were used as negative control and as standard antioxidant of the assay, respectively. The radical scavenging capacity (RSC) (\%) of DPPH radicals was calculated as:

$$
\operatorname{RSC}(\%)=\left(\frac{\left(\mathrm{A}_{0}-\mathrm{A}_{1}\right)}{\mathrm{A}_{0}}\right) \times 100
$$

where $A_{0}$ is the absorbance of the negative control and $A_{1}$ is the absorbance of the extracts. The concentration of sample required to reduce $50 \%$ of DPPH radicals $\left(\mathrm{IC}_{50}\right)$ is calculated from linear regression analysis. A low $\mathrm{IC}_{50}$ indicates a high radical scavenging capacity.

Statistical analyses: To assess the effect of the studied parameters (class of altitude, the characteristic tree of the ecosystem where the rosemary grows and the forest of origin) over the essential oil yield, composition and the antioxidant activity across the different localities, a one-way analysis of variance (ANOVA) was carried out. Noting that we used for the ANOVA analysis the altitude classes figured on Fig. 1. Results were considered statistically significant when $\mathrm{P}<0.05$.

To study the affinity between the essential oil belonging to different localities, a hierarchical cluster analysis (HCA) was conducted with the Euclidean distance as a measure of dissimilarity noting that we considered in those calculations the 20 major compounds, which has a mean value of at least $0.15 \%$ of the total composition. All the analyses were conducted using SPSS software, version 19 (IBM SPSS, Chicago, IL, USA).

\section{RESULTS AND DISCUSSION}

Yield of the essential oils: As listed in Table-2, the essential oil yields of the tested samples ranged between 1.09 and $2.81 \%$. The lowest oil yields was found in Lalla Mimouna (Debdou forest, Province of Taourirt) while the highest in the sample harvested from Flouch (Debdou forest, Province of Taourirt). Statistical analysis showed no significant variation according to the altitude or the associated vegetation (the dominant tree where the rosemary shrub grows). Thus, this variability could be attributed mainly to genetic factors and geographical origin that might stimulate the essential oil production by the rosemary plants. The age of the plant can also be responsible of this variability $[37,38]$.

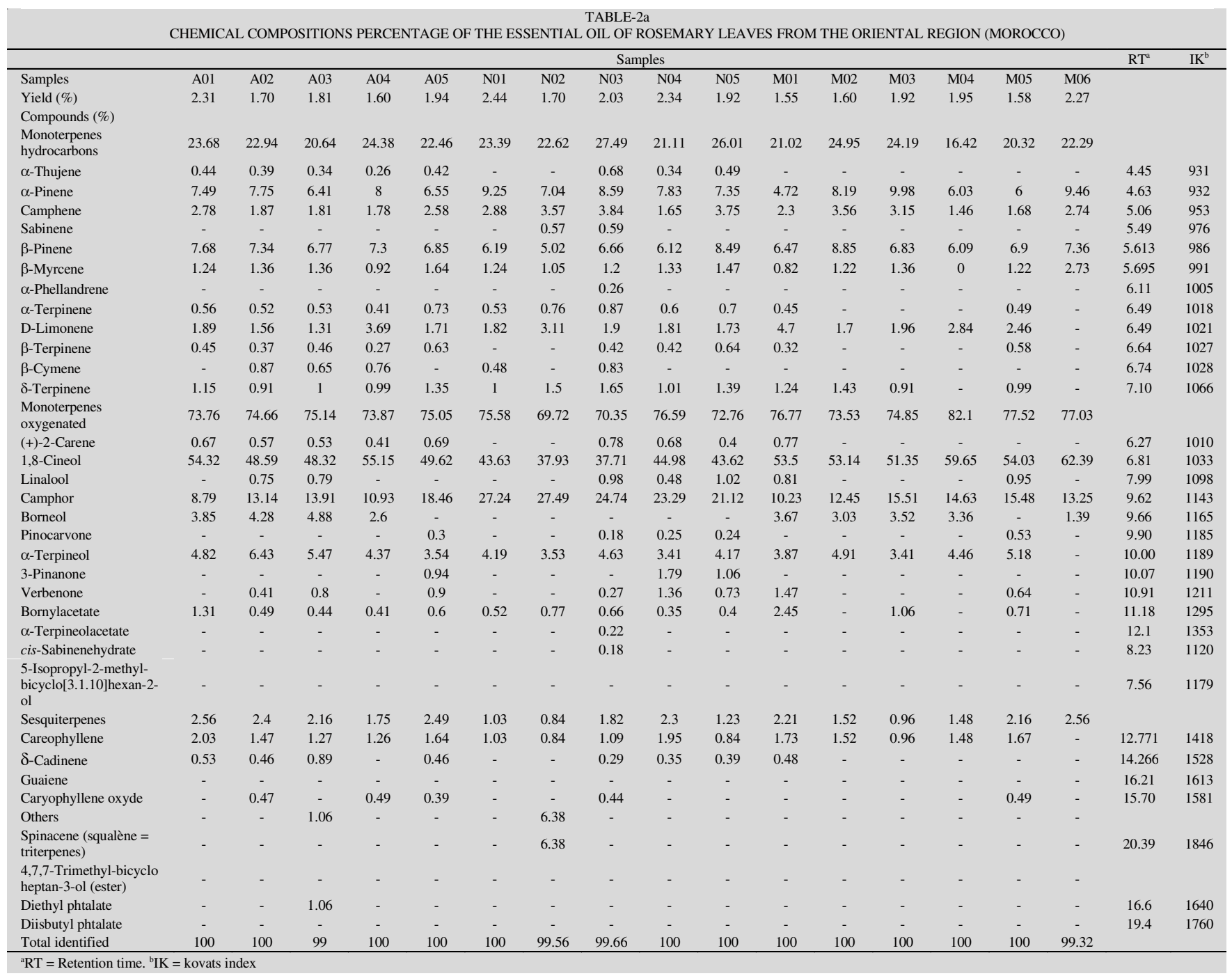




\begin{tabular}{|c|c|c|c|c|c|c|c|c|c|c|c|c|c|c|}
\hline & \multicolumn{12}{|c|}{ Samples } & \multirow[t]{2}{*}{$\mathrm{RT}^{\mathrm{a}}$} & \multirow[t]{2}{*}{$\mathrm{IK}^{\mathrm{b}}$} \\
\hline & D01 & D02 & D03 & D04 & D05 & D06 & D07 & D08 & D09 & D10 & D11 & D12 & & \\
\hline Yield (\%) & 1.90 & 1.66 & 1.49 & 1.62 & 1.58 & 2.63 & 1.83 & 2.32 & 1.33 & 1.09 & 2.81 & 1.69 & & \\
\hline \multicolumn{15}{|l|}{ Compounds (\%) } \\
\hline Monoterpenes hydrocarbons & 19.44 & 14.75 & 22.45 & 9.35 & 27.52 & 23.07 & 20.86 & 21.84 & 25.27 & 30.45 & 20.36 & 21.18 & & \\
\hline$\alpha$-Thujene & - & - & - & - & 0.42 & - & - & 0.33 & 0.48 & 0.56 & - & - & 4.45 & 931 \\
\hline$\alpha$-Pinene & 6.25 & 5.5 & 7.53 & 3.08 & 9.2 & 7.48 & 6.03 & 7.4 & 7.49 & 8.88 & 7.03 & 7.64 & 4.63 & 932 \\
\hline Camphene & 1.65 & - & 1.85 & 0.84 & 2.63 & 2.6 & 2.17 & 2.37 & 3.18 & 3.16 & 2.42 & 2.7 & 5.06 & 953 \\
\hline Sabinene & - & - & - & - & - & - & - & - & - & 0.16 & - & - & 5.49 & 976 \\
\hline$\beta$-Pinene & 7.58 & 4.4 & 8.4 & 2.83 & 9.49 & 7.58 & 8.63 & 6.64 & 7.75 & 11.17 & 5.98 & 7.17 & 5.613 & 986 \\
\hline$\beta$-Myrcene & 1.23 & 0 & 1.48 & 0.47 & 1.61 & 0.79 & 1.43 & 1.32 & 1.52 & 1.81 & 0.91 & 1.18 & 5.695 & 991 \\
\hline$\alpha$-Phellandrene & - & - & - & - & - & - & - & - & - & - & - & - & 6.11 & 1005 \\
\hline$\alpha$-Terpinene & - & - & - & - & 0.58 & - & - & 0.49 & 0.61 & 0.7 & - & - & 6.49 & 1018 \\
\hline D-Limonene & 1.44 & 4.85 & 1.56 & 1.31 & 1.92 & 3.65 & 1.37 & 1.94 & 1.82 & 2.21 & 3.05 & 1.56 & 6.49 & 1021 \\
\hline$\beta$-Terpinene & - & - & - & - & 0.61 & - & - & 0.45 & 0.51 & 0.57 & - & - & 6.64 & 1027 \\
\hline$\beta$-Cymene & - & - & 0.67 & 0.54 & - & - & - & - & 0.8 & - & - & - & 6.74 & 1028 \\
\hline$\delta$-Terpinene & 1.29 & - & 0.96 & 0.28 & 1.06 & 0.97 & 1.23 & 0.9 & 1.11 & 1.23 & 0.97 & 0.93 & 7.10 & 1066 \\
\hline Monoterpenes oxygenated & 79.72 & 71.87 & 76.55 & 88.33 & 70.67 & 74.88 & 76.97 & 76.49 & 72.63 & 67.25 & 78.86 & 77.43 & & \\
\hline$(+)$-2-Carene & - & - & - & - & 0.72 & - & - & 0.67 & 0.64 & 0.81 & - & - & 6.27 & 1010 \\
\hline 1,8-Cineol & 57.43 & 39.84 & 60.58 & 43.98 & 38.57 & 62.04 & 65.02 & 44.78 & 49.12 & 42.16 & 58.61 & 59.04 & 6.81 & 1033 \\
\hline Linalool & - & - & - & 1.71 & 3.54 & - & - & 1.86 & 0.76 & 0.75 & - & 0.97 & 7.99 & 1098 \\
\hline Camphor & 16.39 & 24.85 & 11.07 & 19.51 & 20.95 & 6.09 & 6.76 & 23.26 & 13.44 & 15.02 & 13.95 & 8.42 & 9.62 & 1143 \\
\hline Borneol & - & - & - & 8.84 & - & 1.76 & - & - & 3.57 & - & 1.97 & 3.53 & 9.66 & 1165 \\
\hline Pinocarvone & - & - & - & - & - & - & - & - & 0.31 & 0.25 & - & - & 9.90 & 1185 \\
\hline$\alpha$-Terpineol & 5.09 & 5.14 & 4.9 & 11.28 & 6.15 & 4.27 & 5.19 & 5.37 & 3.35 & 5.2 & 3.6 & 4.44 & 10.00 & 1189 \\
\hline 3-Pinanone & - & - & - & - & - & - & - & - & 0.71 & 1.5 & - & - & 10.07 & 1190 \\
\hline Verbenone & - & - & - & - & - & - & - & - & - & 0.35 & - & - & 10.91 & 1211 \\
\hline Bornyl acetate & 0.81 & 2.04 & - & 2.26 & 0.74 & 0.72 & - & 0.55 & 0.73 & 0.96 & 0.73 & 1.03 & 11.18 & 1295 \\
\hline$\alpha$-Terpineolacetate & - & - & - & - & - & - & - & - & - & - & - & - & 12.1 & 1353 \\
\hline cis-Sabinenehydrate & - & - & - & - & - & - & - & - & - & 0.25 & - & - & 8.23 & 1120 \\
\hline $\begin{array}{l}\text { 5-isopropyl-2-methylbicyclo[3.1.10]hexan- } \\
\text { 2-ol (carène) }\end{array}$ & - & - & - & 0.75 & - & - & - & - & - & - & - & - & 7.56 & 1179 \\
\hline Sesquiterpenes & 0.84 & 1.38 & 1 & 2.32 & 1.81 & 2.05 & 2.17 & 1.67 & 1.24 & 2.3 & 0.78 & 1.39 & & \\
\hline Careophyllene & 0.84 & 1.38 & 1 & 1.86 & 1.22 & 2.05 & 2.17 & 1.22 & 1.24 & 1.49 & 0.78 & 1.39 & 12.771 & 1418 \\
\hline$\delta$-Cadinene & - & - & - & - & 0.36 & - & - & 0.22 & - & 0.26 & - & - & 14.266 & 1528 \\
\hline Guaiene & - & - & - & - & - & - & - & - & - & - & - & - & 16.21 & 1613 \\
\hline Caryophyllene oxide & - & - & - & 0.46 & 0.23 & - & - & 0.23 & - & 0.55 & - & - & 15.70 & 1581 \\
\hline Others & - & 12 & - & - & - & - & - & - & 0.86 & - & - & - & & \\
\hline Spinacene (squalene = triterpenes) & - & - & - & - & - & - & - & - & - & - & - & - & 20.39 & 1846 \\
\hline 4.7.7-Trimethyl-bicycloheptan-3-ol (ester) & - & 7.65 & - & - & - & - & - & - & - & - & - & - & & \\
\hline Diethyl phtalate & - & 4.35 & - & - & - & - & - & - & 0.86 & - & - & - & 16.6 & 1640 \\
\hline Diisbutyl phtalate & - & - & - & - & - & - & - & - & - & - & - & - & 19.4 & 1760 \\
\hline Total identified & 100 & 100 & 100 & 100 & 100 & 100 & 100 & 100 & 100 & 100 & 100 & 100 & & \\
\hline
\end{tabular}

\begin{tabular}{|c|c|c|c|c|c|c|c|c|c|c|c|c|c|}
\hline \multicolumn{14}{|c|}{$\begin{array}{c}\text { TABLE-2c } \\
\text { CHEMICAL COMPOSITIONS PERCENTAGE OF THE ESSENTIAL OIL OF ROSEMARY LEAVES FROM THE ORIENTAL REGION (MOROCCO) }\end{array}$} \\
\hline & \multicolumn{9}{|c|}{ Samples } & \multirow{2}{*}{$\begin{array}{c}\text { Mean } \\
\text { value of } \\
\text { all the } \\
37 \\
\text { samples }\end{array}$} & \multirow{2}{*}{$\begin{array}{l}\text { Standard } \\
\text { deviation } \\
\text { of all } 37 \\
\text { samples }\end{array}$} & \multirow{2}{*}{$\mathrm{RT}^{\mathrm{a}}$} & \multirow{2}{*}{$\mathrm{IK}^{\mathrm{b}}$} \\
\hline & J01 & $\mathrm{J} 02$ & J03 & J04 & J05 & J06 & J07 & J08 & J09 & & & & \\
\hline Yield (\%) & 1.87 & 2.42 & 1.82 & 1.89 & 1.89 & 1.96 & 2.03 & 1.70 & 2.37 & 1.91 & 0.28 & & \\
\hline \multicolumn{14}{|l|}{ Compounds (\%) } \\
\hline Monoterpenes hydrocarbons & 23.75 & 26.55 & 26.46 & 23.08 & 22.24 & 24.87 & 23.28 & 26.9 & 20.66 & 22.66 & 2.58 & & \\
\hline$\alpha$-Thujene & - & - & 0.42 & - & - & 0.45 & - & 1.04 & - & 0.19 & 0.23 & 4.45 & 931 \\
\hline$\alpha$-Pinene & 7.82 & 9.18 & 7.91 & 8.74 & 7.41 & 8.64 & 7.65 & 7.33 & 7.02 & 7.46 & 0.98 & 4.63 & 932 \\
\hline Camphene & 2.32 & 2.71 & 2.58 & 3.43 & 2.04 & 2.87 & 1.34 & 3.65 & 1.85 & 2.43 & 0.66 & 5.06 & 953 \\
\hline Sabinene & - & - & - & - & - & - & - & 1.22 & - & 0.07 & 0.12 & 5.49 & 976 \\
\hline$\beta$-Pinene & 6.81 & 8.12 & 9.34 & 9.16 & 8.02 & 8.83 & 8.06 & 6.64 & 7.65 & 7.33 & 1.09 & 5.613 & 986 \\
\hline$\beta$-Myrcene & 0.87 & 1.25 & 1.39 & - & 1.17 & 0.69 & 1 & 0.75 & 1.14 & 1.14 & 0.35 & 5.695 & 991 \\
\hline$\alpha$-Phellandrene & - & - & - & - & - & - & - & - & - & 0.01 & 0.01 & 6.11 & 1005 \\
\hline$\alpha$-Terpinene & 0.7 & 0.67 & 0.57 & - & 0.54 & 0.5 & - & 1.19 & - & 0.37 & 0.30 & 6.49 & 1018 \\
\hline D-Limonene & 1.77 & 1.78 & 1.78 & 1.75 & 1.66 & 1.59 & 4.26 & 1.5 & 1.61 & 2.12 & 0.73 & 6.49 & 1021 \\
\hline$\beta$-Terpinene & 0.41 & - & 0.64 & - & 0.39 & - & - & - & - & 0.22 & 0.24 & 6.64 & 1027 \\
\hline$\beta$-Cymene & 1.18 & 1.1 & 0.59 & - & - & - & - & 1.01 & - & 0.26 & 0.35 & 6.74 & 1028 \\
\hline$\delta$-Terpinene & 1.87 & 1.74 & 1.24 & - & 1.01 & 1.3 & 0.97 & 2.57 & 1.39 & 1.07 & 0.35 & 7.10 & 1066 \\
\hline Monoterpenes oxygenated & 72.85 & 71.83 & 65.25 & 75.56 & 75.61 & 74.57 & 73.88 & 71.33 & 68.87 & 74.61 & 2.89 & & \\
\hline$(+)$-2-Carene & 0.32 & 0.52 & 0.61 & - & 0.73 & 0.42 & - & 0.63 & - & 0.31 & 0.30 & 6.27 & 1010 \\
\hline 1,8-Cineol & 46.71 & 46.51 & 46.1 & 52.89 & 51.39 & 50.21 & 61.98 & 49.61 & 53.25 & 50.75 & 6.07 & 6.81 & 1033 \\
\hline Linalool & 0.44 & 0.83 & 0.57 & - & 0.69 & - & - & - & - & 0.48 & 0.53 & 7.99 & 1098 \\
\hline Camphor & 20.57 & 19.28 & 12.38 & 17.04 & 17.23 & 20.64 & 8.59 & 16.28 & 15.62 & 16.16 & 4.52 & 9.62 & 1143 \\
\hline Borneol & - & - & - & - & - & - & - & - & - & 1.36 & 1.69 & 9.66 & 1165 \\
\hline Pinocarvone & - & - & - & - & - & - & - & - & - & 0.06 & 0.09 & 9.90 & 1185 \\
\hline
\end{tabular}




\begin{tabular}{|c|c|c|c|c|c|c|c|c|c|c|c|c|c|}
\hline$\alpha$-Terpineol & 4.3 & 3.99 & 4.49 & 4.09 & 4.58 & 3.3 & 3.31 & 4.03 & - & 4.39 & 1.01 & 10.00 & 1189 \\
\hline 3-Pinanone & - & - & - & - & - & - & - & - & - & 0.16 & 0.28 & 10.07 & 1190 \\
\hline Verbenone & - & - & - & - & 0.38 & - & - & - & - & 0.20 & 0.29 & 10.91 & 1211 \\
\hline Bornyl acetate & 0.51 & 0.7 & 1.1 & 1.54 & 0.61 & - & - & 0.78 & - & 0.70 & 0.42 & 11.18 & 1295 \\
\hline$\alpha$-Terpineolacetate & - & - & - & - & - & - & - & - & - & 0.01 & 0.01 & 12.1 & 1353 \\
\hline cis-Sabinene hydrate & - & - & - & - & - & - & - & - & - & 0.01 & 0.02 & 8.23 & 1120 \\
\hline $\begin{array}{l}\text { 5-Isopropyl-2-methylbicyclo- } \\
\text { [3.1.10]hexan-2-ol }\end{array}$ & - & - & - & - & - & - & - & - & - & 0.02 & 0.04 & 7.56 & 1179 \\
\hline Sesquiterpenes & 3.4 & 1.62 & 4.61 & 1.36 & 2.15 & 0.56 & 2.84 & 1.77 & 4.27 & 1.85 & 0.69 & & \\
\hline Careophyllene & 2.26 & 1.62 & 3.4 & 1.36 & 1.53 & 0.56 & 1.97 & 1.77 & 1.91 & 1.45 & 0.43 & 12.771 & 1418 \\
\hline$\delta$-Cadinene & 0.66 & - & 0.66 & - & 0.62 & - & 0.87 & - & 1.12 & 0.23 & 0.27 & 14.266 & 1528 \\
\hline Guaiene & - & - & - & - & - & - & - & - & 1.24 & 0.03 & 0.07 & 16.21 & 1613 \\
\hline Caryophyllene oxide & 0.48 & - & 0.55 & - & - & - & - & - & - & 0.13 & 0.18 & 15.70 & 1581 \\
\hline Others & 0 & 0 & 0 & 0 & 0 & 0 & 0 & 0 & 4.2 & 0.66 & 1.15 & & \\
\hline Spinacene (squalène $=$ triterpenes) & - & - & - & - & - & - & - & - & - & 0.17 & 0.34 & 20.39 & 1846 \\
\hline $\begin{array}{l}\text { 4.7.7-Trimethyl-bicyclo heptan-3-ol } \\
\text { (ester) }\end{array}$ & - & - & - & - & - & - & - & - & - & 0.21 & 0.40 & & \\
\hline Diethyl phtalate & - & - & - & - & - & - & - & - & 3.06 & 0.25 & 0.45 & 16.6 & 1640 \\
\hline Diisobutyl phtalate & - & - & - & - & - & - & - & - & 1.14 & 0.03 & 0.06 & 19.4 & 1760 \\
\hline Total identified & 100 & 100 & 96.32 & 100 & 100 & 100 & 100 & 100 & 98 & & & & \\
\hline
\end{tabular}

${ }^{\mathrm{a}} \mathrm{RT}=$ retention time, ${ }^{\mathrm{b}} \mathrm{IK}=$ Kovats index

Different reports can be found in literature concerning rosemary essential oil yield and how it varies depending on the plant location and ecosystem conditions. Khia et al. [39] studied Moroccan Rosmarinus officinalis in the region of Taza, which yielded from $1.2 \%$ in Aknoul (North of Taza) to 2.21 $\%$ in Rchida (South of Taza); however, they didn't attribute this difference to the ecological conditions. Also, in the region of Hammamat in Tunisia, Rosmarinis officinalis yielded from 1.6 to $2.29 \%$ without registering a strong link between ecological conditions and the yield [40]. Angioni et al. [9] studied wild Sardinian Rosmarinus officinalis, from different locations, reported differences at the essential oil yield, however, they didn't relate these difference to climatic or edaphic condition. Concerning Spanish Rosemary, Varela et al. [41] found a yield ranging from 0.82 to 2.99 . While Jordan et al. [30] reported that the essential oil yield varies from 1.74 to $2.58 \%$. Based on results, it is suggested that rosemary essential oil is influenced by the habitat in which the plants grow. By contrast, the influence of ecological factor that modifies this parameter remains not clear.

Composition of the essential oils: Concerning the essential oil volatile profile, chromatographic analysis through the total ion current (TIC) chromatograms of the individual samples allowed the identification of 34 major components, which represent between 96.32 and $100 \%$ of the volatile components identified in rosemary essential oil (Table-2). However, quantitatively speaking, the chemical composition of essential oil submits to variations over the different locations studied (Fig. 2). The relative concentration of 1,8-cineol, camphor and $\alpha$-pinene, the three components which determine the rosemary essential oil chemotype, range from $37.71 \%, 6.09 \%$, 3.08$65.02 \%, 27.49 \%, 9.98 \%$ respectively mentioning that the highest content on 1,8-cineol is registered in Zoubia (Debdou Forest). In addition, we point out that $\beta$-pinene (2.83-11.17\%) and camphene (0.84-3.93\%) are present, with less importance, in the majority of the harvested samples. The other components as $\beta$-myrcene, borneol, $\alpha$-terpineol and bornyl acetate show low concentrations (excepted for Wizaght where we found 11.18 and $8.84 \%$ of $\alpha$-terpineol and borneol, respectively). These major components were also reported to be present in different regions around the world with different concentrations. Whereas $\alpha$-pinene is the major component in Rosmarinus officinalis oil from Poland [11], camphor and 1,8-cineol in Spain [42], $\alpha$-pinene and 1,8-cineol in Iran [43] and myrcene for the Brazilian Rosemary [23]. Concerning, the Moroccan Rosmarinus officinalis, our finding were close to the results of Ait-ouazzou et al. [44] and Ghadraoui et al. [45] who reported a content of 1,8-cineol of 43 and $42 \%$, respectively.

Nevertheless, the concentration of essential oil component didn't show statistically significant difference between the zones studied depending to the altitude or the vegetal association. However, there is a significant variation according to the forest where samples were harvested. Table-3 illustrates the mean value of the percentage of the two major compounds (1,8-cineol and camphor) contained in rosemary essential oil sorted by forest. Thus, we report that the mean value related to 1,8-cineol for the forest of Mkam are the highest (55.67 \pm 3.56 $\%$ ) followed by the forest of Debdou (51.76 $\pm 8.68 \%$ ). Right after, we find Ayate $(50.20 \pm 2.82 \%)$ and Beni Yaala forest $(50.96 \pm 3.48 \%)$. While the lowest content is in Nerguechoum forest $(41.57 \pm 3.00 \%)$. But, we have to mention that the standard deviation remains relatively high especially in Debdou forest and this could be related to its much expanded area. Those results lead us to conclude that the essential oil composition is influenced by the habitat and the origin of the plant. Those results are in agreement with those published by Zaouali et al. [46] who affirmed that variations in the chemical composition of rosemary essential oil from Tunisia should be attributed to varieties and location rather than ecologic conditions.

TABLE-3

MEAN VALUE THE PERCENTAGE OF 1,8-CINEOL AND CAMPHOR CONTAINED IN ROSEMARY ESSENTIAL OIL, SORTED BY FOREST

\begin{tabular}{ccccc}
\hline Forest & Ayat & Nerguechoum & Mkam & Beni Yaala \\
\hline 1,8 -Cineol $(\%)$ & $50.20 \pm 2.82$ & $41.57 \pm 3.00$ & $55.67 \pm 3.56$ & $51.76 \pm 8.68$ \\
Camphor $(\%)$ & $13.04 \pm 2.54$ & $24.77 \pm 2.77$ & $13.59 \pm 1.61$ & $14.97 \pm 5.02$ \\
\hline
\end{tabular}




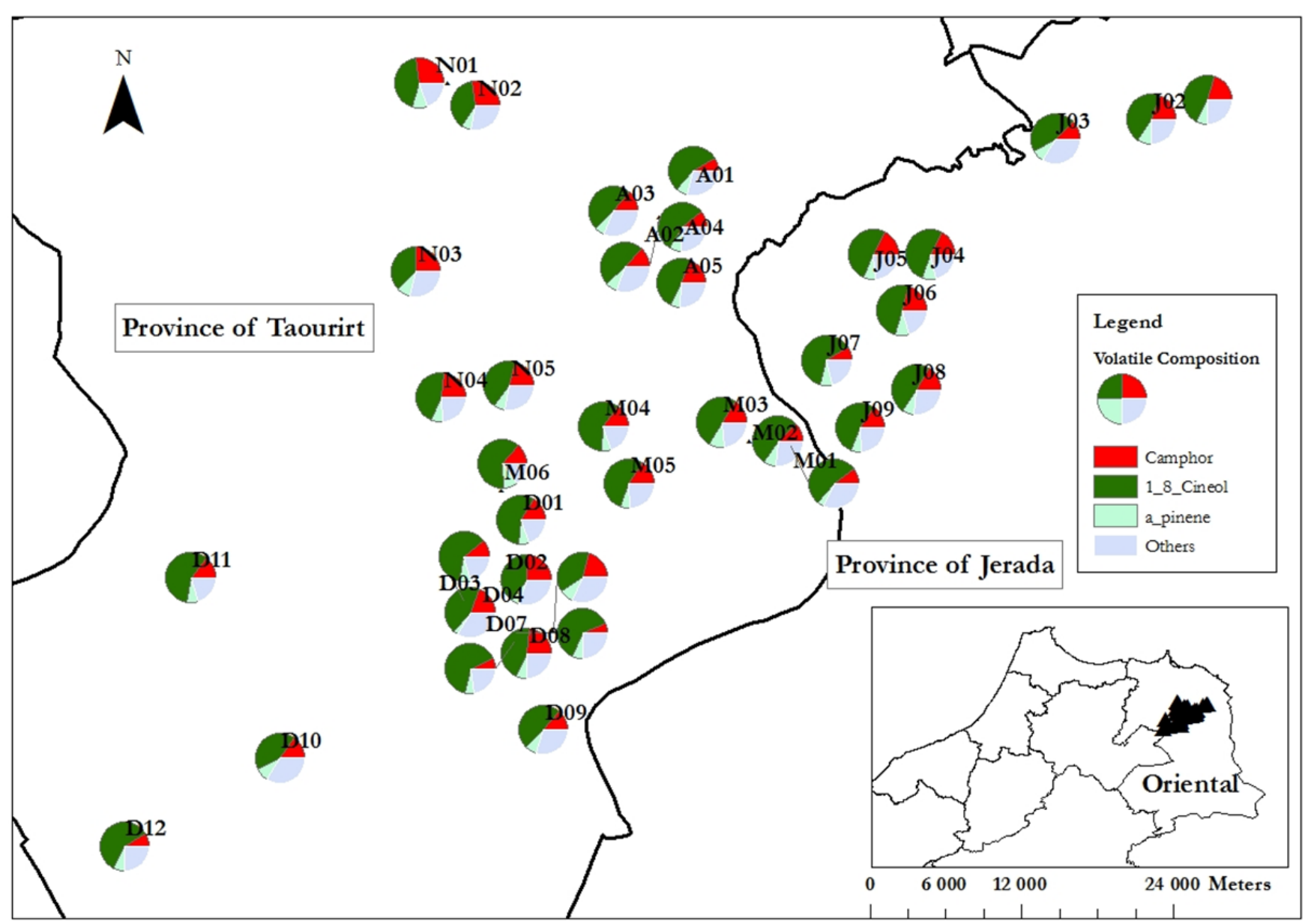

Fig. 2. Volatile variability of rosemary essential oil of the provinces of Jerada and Taourirt, Oriental region (Morocco)

Regarding to molecule groups as shown in Table-2, the monotepenes hydrocarbons range from $9.35 \%$ in Wizghad (Debdou) to $30.45 \%$ in Lalla Mimouna (Debdou) respectively with a mean value of $22.65 \pm 2.58 \%$. They are represented mainly by $\alpha$-pinene, camphene, $\beta$-pinene, myrcene. Mean while monoterpenes oxygenated, are represented by 1,8-cineol, camphor, $\alpha$-terpineol and borneol and they constitute the main part of the essential oil with a proportion of $65.25 \%$ (Khtitila) to $88.33 \%$ (Wizaght) with a mean value of $74.61 \pm 2.88$. While the other groups such as sesquiterpenes represent $1.84 \pm 0.69$ $\%$ on average. Those results are in accordance with the previous finding $[19,25]$.

The cluster analysis carried out on the essential oil composition is represented in the dendrogram reported in Fig. 3, which reflects the large compositional complexity of rosemary essential oils. The analysis of this graph allowed subdividing the samples in 2 main groups: Group I can be divided into 4 subgroups: Group A where there is a content of 1,8-cineol varying between 48.32 and $52.89 \%$ and a camphor content varying between 13.14 and $20.64 \%$ and this is mainly found in the samples harvested in Beni Yaala and Ayat forest. Group B where 1,8-cineol varies from 53.14 to $59.55 \%$ and camphor from 8.79 to $16.39 \%$ found in Mkam and Ayat forest. Group C which encompasses samples with (42.16-46.1\%) of 1,8cineol and (12.38-15.02\%) of camphor. Group D is characterized by the highest content of 1,8-cineol (59.04-65.02\%) and the least of camphor (6.09-13.25 \%) and it's found for instance in the Zoubia (center of Debdou Forest). Group II which contain 2 sub-groups: Group E with the lowest content of 1,8-cineol (37.71-43.63\%), while the camphor content varies from 24.74 to $27.49 \%$; this subgroup is represented by the northern samples of the forest of Nerguechoum. Group F where there is just one sample of Wizaght with $43.98 \%$ of 1,8-cineol and $19.51 \%$ of camphor. This sample is characterized by a relative high content of $\alpha$-terpineol and borneol (respectively 11.18 and $8.84 \%$ ).

DPPH radical scavenging capacity: We studied the radical scavenging capacity (RSC) of 37 essential oils from rosemary leaves by the original DPPH test of Kumar et al. [36]. All the analyzed samples showed an increase in radical scavenging capacity, in agreement with the oil concentration (Table-4). The essential oil from Lalla Mimouna (Debdou forest) was the most active with $(29.02 \pm 1.04 \mu \mathrm{L} / \mathrm{mL})$ and the less active was Wizaght (Debdou forest) sample with (43.95 \pm $1.11 \mu \mathrm{L} / \mathrm{mL}$ ). The one-way ANOVA showed a no significant variability among the samples according to the forest, altitude or the associated vegetal species. Compared with ascorbic acid (Table-4), which is a well-known potent antioxidant $\left(\mathrm{IC}_{50}=\right.$ $22.65 \pm 0.61 \mu \mathrm{L} / \mathrm{mL}$ with $\left.\mathrm{r}^{2}=0.97\right)$, the essential oils were less active. Nevertheless, it still could be considered as a strong antioxidant. Present findings are in accordance with other publications $[25,47,48]$. 


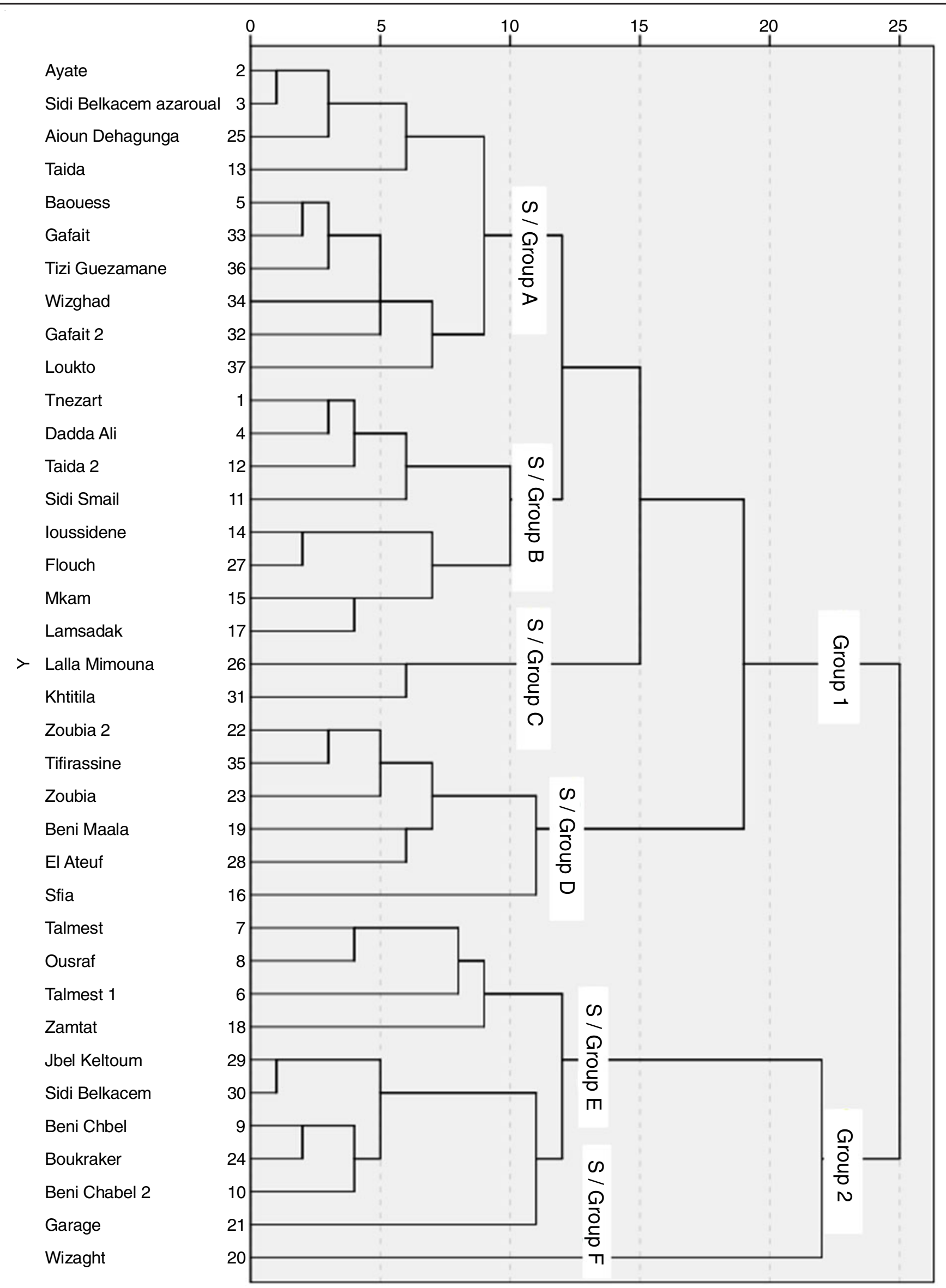

Fig. 3. Cluster dendrogram using the main 20 constituents (and with an average content more than $0.15 \%$ ) of the 37 populations of rosemary of Oriental Region (Taourirt and Jerada provinces) 
FREE RADICAL-SCAVENGING CAPACITY OF ROSEMARY ESSENTIAL OIL OF THE ORIENTAL REGION IN MOROCCO LAND THE TOTAL OF MONOTERPENES HYDROCARBONS (MH) AND MONOTERPENES OXIGINATED (MO)

\begin{tabular}{|c|c|c|c|c|c|c|c|c|c|}
\hline \multirow{2}{*}{ Sample } & \multirow{2}{*}{ Location name } & \multicolumn{4}{|c|}{ Concentration of essential oil $(\mu \mathrm{L} / \mathrm{mL})$} & \multirow{2}{*}{$\mathrm{R}^{2 \mathrm{a}}$} & \multirow{2}{*}{$\begin{array}{c}\mathrm{DPPH} \mathrm{IC}_{50}^{\mathrm{b}} \\
(\mu \mathrm{L} / \mathrm{mL})\end{array}$} & \multirow{2}{*}{$\begin{array}{l}\text { Total } \\
\text { MH }\end{array}$} & \multirow{2}{*}{$\begin{array}{c}\text { Total } \\
\text { MO }\end{array}$} \\
\hline & & 20 & 40 & 60 & 80 & & & & \\
\hline A01 & Tnezart & 40.16 & 57.83 & 63.65 & 74.20 & 0.95 & 33.52 & 23.68 & 73.76 \\
\hline A02 & Ayate & 43.85 & 52.69 & 65.26 & 74.65 & 0.96 & 32.69 & 22.94 & 74.66 \\
\hline A03 & Sidi Belkacemazaroual & 45.83 & 51.45 & 62.77 & 76.03 & 0.97 & 32.33 & 20.64 & 75.14 \\
\hline A04 & Dadda Ali & 42.16 & 58.34 & 62.11 & 73.05 & 0.94 & 31.53 & 24.38 & 73.87 \\
\hline A05 & Baouess & 46.14 & 51.03 & 63.16 & 75.66 & 0.96 & 32.16 & 22.46 & 75.05 \\
\hline N01 & Talmest1 & 42.90 & 55.26 & 61.15 & 73.22 & 0.98 & 33.22 & 23.39 & 75.58 \\
\hline N02 & Talmest & 42.69 & 52.09 & 62.78 & 78.63 & 0.98 & 34.76 & 22.62 & 69.72 \\
\hline N03 & Ousraf & 42.68 & 56.89 & 64.98 & 71.36 & 0.96 & 30.97 & 27.49 & 70.35 \\
\hline N04 & Beni Chbel & 43.97 & 53.09 & 65.16 & 74.25 & 0.99 & 32.31 & 21.11 & 76.59 \\
\hline N05 & Beni Chbel 2 & 43.20 & 56.20 & 64.2 & 72.90 & 0.98 & 31.23 & 26.01 & 72.76 \\
\hline M01 & Sidi Smail & 44.96 & 51.68 & 63.98 & 71.98 & 0.98 & 32.59 & 21.02 & 76.77 \\
\hline M02 & Taida 2 & 41.26 & 53.69 & 66.12 & 76.50 & 0.99 & 34.15 & 24.95 & 73.53 \\
\hline M03 & Taida & 42.12 & 57.30 & 64.05 & 72.29 & 0.96 & 31.64 & 24.19 & 74.85 \\
\hline M04 & Ioussidene & 40.05 & 55.18 & 67.12 & 75.62 & 0.98 & 34.01 & 16.42 & 82.1 \\
\hline M05 & Mkam & 44.50 & 53.26 & 64.80 & 70.15 & 0.98 & 31.56 & 20.32 & 77.52 \\
\hline M06 & Sfia & 42.58 & 54.78 & 66.67 & 72.25 & 0.97 & 32.06 & 22.29 & 77.03 \\
\hline D01 & Lamsadak & 40.15 & 57.22 & 64.10 & 72.22 & 0.95 & 33.68 & 19.44 & 79.72 \\
\hline D02 & Zamtat & 38.15 & 55.14 & 64.20 & 73.25 & 0.97 & 36.63 & 14.75 & 71.87 \\
\hline D03 & Beni Mâala & 43.15 & 54.69 & 66.89 & 74.58 & 0.99 & 31.57 & 22.45 & 76.55 \\
\hline D04 & Wizaght & 34.20 & 52.20 & 60.11 & 69.15 & 0.96 & 43.45 & 9.35 & 88.33 \\
\hline D05 & Garage & 44.20 & 57.12 & 63.11 & 73.80 & 0.98 & 29.83 & 27.52 & 70.67 \\
\hline D06 & Zoubia 2 & 42.56 & 54.88 & 66.12 & 75.65 & 0.99 & 32.3 & 23.07 & 74.88 \\
\hline D07 & Zoubia & 41.78 & 55.25 & 66.12 & 73.25 & 0.98 & 32.73 & 20.86 & 76.97 \\
\hline D08 & Boukraker & 41.25 & 57.48 & 66.78 & 73.98 & 0.96 & 31.65 & 21.84 & 76.49 \\
\hline D09 & Aioun Dehaguna & 41.62 & 58.20 & 66.34 & 76.02 & 0.97 & 31.09 & 25.27 & 72.63 \\
\hline D10 & Lalla Mimouna & 42.69 & 59.66 & 66.26 & 75.75 & 0.96 & 29.09 & 30.45 & 67.25 \\
\hline D11 & Flouch & 40.69 & 56.56 & 64.23 & 72.12 & 0.96 & 33.57 & 20.36 & 78.86 \\
\hline D12 & El Ateuf & 42.87 & 54.65 & 64.10 & 73.45 & 0.99 & 32.66 & 21.18 & 77.43 \\
\hline J01 & Jbel Keltoum & 41.12 & 56.89 & 64.13 & 76.12 & 0.98 & 32.97 & 23.75 & 72.85 \\
\hline $\mathrm{J} 02$ & Sidi Belkacem & 42.56 & 58.21 & 64.89 & 75.69 & 0.97 & 30.52 & 26.55 & 71.83 \\
\hline $\mathrm{J} 03$ & Khtitila & 44.15 & 57.20 & 62.20 & 75.32 & 0.97 & 30.3 & 26.46 & 65.25 \\
\hline J04 & Gafait 2 & 40.14 & 58.64 & 67.05 & 74.22 & 0.94 & 31.91 & 23.08 & 75.56 \\
\hline $\mathrm{J} 05$ & Gafait & 43.20 & 54.76 & 63.95 & 70.17 & 0.98 & 32.24 & 22.24 & 75.61 \\
\hline J06 & Wizghad & 42.88 & 55.43 & 65.67 & 72.19 & 0.98 & 31.63 & 24.87 & 74.57 \\
\hline J07 & Tifirassine & 41.98 & 55.06 & 68.35 & 76.14 & 0.98 & 32.11 & 23.28 & 73.88 \\
\hline J08 & Tizi Guezmane & 42.62 & 58.76 & 63.26 & 76.18 & 0.96 & 30.64 & 26.9 & 71.33 \\
\hline J09 & Loukto & 40.12 & 57.11 & 62.72 & 72.20 & 0.95 & 34.24 & 20.66 & 68.87 \\
\hline Acid ascorbic $^{c}$ & - & 46.61 & 63.34 & 71.16 & 82.77 & 0.97 & 22.65 & - & - \\
\hline
\end{tabular}

${ }^{a} \mathrm{R}^{2}$, the regression coefficient used to measure the linear dependence between the essential oil concentration and the percentage of radical scavenging capacity; ' Essential oil concentration required to scavenge $50 \%$ of DPPH solution; ${ }^{\mathrm{b}}$ Acid ascorbic used as a reference antioxidant.

It is noticed in present study that this activity is negatively in line with the content of monoterpenes hydrocarbons $\left(\mathrm{R}^{2}=\right.$ $74 \%)$. Many studies pointed out that the capacity of an antioxidant component to scavenge DPPH mainly relate to its hydrogen donating ability, which is directly depends to the presence of the abundance of monoterpenes hydrocarbons which are rich of functional groups [25].

\section{Conclusion}

The present research shown that Rosmarinus officinalis of the Oriental is characterized by 1,8-cineol as a major component for all the locations studied. We also reported that the camphor is present with relatively high concentrations. Nevertheless, we highlight the considerable volatile variability, concerning the content of those major compounds, among the population, which can be explained mainly by the genetic and the geographic factor rather than the altitude or the associated vegetation (which defines the ecosystem). Besides, the antioxidant activity of their essential oils is deemed very important which could be used as potent antioxidant in food and pharmaceutical industry.

\section{ACKNOWLEDGEMENTS}

The authors are grateful to the Regional Direction of Water and Forests of the Region of Oriental (Morocco) and the Forest Management and Studies Service of Oriental for supporting our work during the collection of samples.

\section{CONFLICT OF INTEREST}

The authors declare that there is no conflict of interests regarding the publication of this article. 


\section{REFERENCES}

1. A. Benabid, Flore et Écosystèmes Du Maroc: Évaluation et Préservation de La Biodiversité (2000).

2. M. Miroddi, G. Calapai, S. Isola, P.L. Minciullo and S. Gangemi, Allergol. Immunopathol., 42, 616 (2014); https://doi.org/10.1016/i.aller.2013.04.006.

3. J. Herrera, Ann. Bot., 95, 431 (2004); https://doi.org/10.1093/aob/mci041.

4. R. Mehdioui and A. Kahouadji, Bull. l'Institut Sci. Rabat Sect. Sci. La Vie, 29, 11 (2007).

5. M. Fennane and M. Ibn Tattou, Flora Mediterr., 9, 113 (1999).

6. A. Porte, R.L.O. Godoy, D. Lopes, M. Koketsu, S.L. Gonçalves and H.S. Torquilho, J. Essent. Oil Res., 12, 577 (2000);

https://doi.org/10.1080/10412905.2000.9712163.

7. H.E. Katerinopoulos, G. Pagona, A. Afratis, N. Stratigakis and N. Roditakis, J. Chem. Ecol., 31, 111 (2005); https://doi.org/10.1007/s10886-005-0978-0.

8. B.I. Bozin, N. Mimica-Dukic, I. Samojlik and E. Jovin, J. Agric. Food Chem., 55, 7879 (2007); https://doi.org/10.1021/jf0715323.

9. A. Angioni, A. Barra, E. Cereti, D. Barile, J.D. Coïsson, M. Arlorio, S. Dessi, V. Coroneo and P. Cabras, J. Agric. Food Chem., 52, 3530 (2004); https://doi.org/10.1021/jf049913t.

10. M.C. Díaz-Maroto, M.S. Pérez-Coello, E. Sánchez-Palomo and M.A. González Viñas, J. Sens. Stud., 22, 34 (2007); https://doi.org/10.1111/j.1745-459X.2007.00093.x.

11. A. Szumny, A. Figiel, A. Gutiérrez-Ortíz and Á.A. Carbonell-Barrachina, J. Food Eng., 97, 253 (2010); https://doi.org/10.1016/j.jfoodeng.2009.10.019.

12. D.V. Lakusic, M.S. Ristic, V.N. Slavkovska, J.B. Sinzar-Sekulic and B.S. Lakusic, Chem. Biodivers., 9, 1286 (2012); https://doi.org/10.1002/cbdv.201100427.

13. N. Chahboun, A. Esmail, N. Rhaiem, H. Abed, R. Amiyare, M. Barrahi, M. Berrabeh, H. Oudda and M. Ouhssine, Der Pharma Chemica, 6, 367 (2014)

14. O. Yesil-Celiktas, G. Girgin, H. Orhan, H.J. Wichers, E. Bedir and F. Vardar-Sukan, Eur. Food Res. Technol., 224, 443 (2007); https://doi.org/10.1007/s00217-006-0306-0.

15. C. Takayama, F.M. de-Faria, A.C.A. de Almeida, R.J. Dunder, L.P. Manzo, E.A.R. Socca, L.M. Batista, M.J. Salvador, A.R.M. SouzaBrito and A. Luiz-Ferreira, Asian Pac. J. Trop. Biomed., 6, 677 (2016); https://doi.org/10.1016/j.apjtb.2015.09.027.

16. R. Sedighi, Y. Zhao, A. Yerke and S. Sang, Curr. Opin. Food Sci., 2, 58 (2015); https://doi.org/10.1016/j.cofs.2015.02.002.

17. Y. Jiang, N. Wu, Y.-J. Fu, W. Wang, M. Luo, C.J. Zhao, Y.G. Zu and X.L. Liu, Environ. Toxicol. Pharmacol., 32, 63 (2011); https://doi.org/10.1016/j.etap.2011.03.011.

18. G. Pesavento, C. Calonico, A.R. Bilia, M. Barnabei, F. Calesini, R. Addona, L. Mencarelli, L. Carmagnini, M.C. Di Martino and A. Lo Nostro, Food Control, 54, 188 (2015); https://doi.org/10.1016/j.foodcont.2015.01.045.

19. O.O. Okoh, A.P. Sadimenko and A.J. Afolayan, Food Chem., 120, 308 (2010); https://doi.org/10.1016/j.foodchem.2009.09.084.

20. S. Hmiri, H. Harhar and M. Rahouti, J. Mater. Environ. Sci., 6, 2967 (2015).

21. B.S. Badreddine, E. Olfa, D. Samir, C. Hnia and B.J.M. Lahbib, Asian Pac. J. Trop. Med., 8, 98 (2015); https://doi.org/10.1016/S1995-7645(14)60298-4.

22. W. Wang, N. Li, M. Luo, Y. Zu and T. Efferth, Molecules, 17, 2704 (2012); https://doi.org/10.3390/molecules17032704.

23. I. Takaki, L.E. Bersani-Amado, A. Vendruscolo, S.M. Sartoretto, S.P. Diniz, C.A. Bersani-Amado and R.K.N. Cuman, J. Med. Food, 11, 741 (2008); https://doi.org/10.1089/jmf.2007.0524.

24. M.A. Velázquez-González, J.G. Gonzalez-Rodriguez, M.G. ValladaresCisneros and I.A. Hermoso-Diaz, Am. J. Anal. Chem., 5, 55 (2014); https://doi.org/10.4236/ajac.2014.52009.
25. M. Tahri, B. Imelouane, H. Amhamdi and A. Elbachiri, J. Mater. Environ. Sci., 6, 666 (2015).

26. D.R. Berdahl and J. Mckeague, Handbook of Antioxidants Food Preservatives, pp. 177-217 (2015).

27. O. Blokhina, E. Virolainen and K.V. Fagerstedt, Ann. Bot., 91, 179 (2003); https://doi.org/10.1093/aob/mcf118.

28. I. Kivrak, M.E. Duru, M. Öztürk, N. Mercan, M. Harmandar and G. Topçu, Food Chem., 116, 470 (2009); https://doi.org/10.1016/j.foodchem.2009.02.069.

29. Y. Zaouali, H. Chograni, R. Trimech and M. Boussaid, Ind. Crops Prod., 38, 166 (2012); https://doi.org/10.1016/j.indcrop.2012.01.011.

30. M.J. Jordán, V. Lax, M.C. Rota, S. Lorán and J.A. Sotomayor, Food Control, 30, 463 (2013); https://doi.org/10.1016/j.foodcont.2012.07.029.

31. M.J. Jordán, V. Lax, M.C. Rota, S. Lorán and J.A. Sotomayor, Ind. Crops Prod., 48, 144 (2013); https://doi.org/10.1016/j.indcrop.2013.04.031.

32. O. Fadel, Z. Ghazi, L. Mouni, N. Benchat, M. Ramdani, H. Amhamdi, J. Wathelet, A. Asehraoui and R. Charof, J. Mater. Environ. Sci., 2, 112 (2011).

33. E.M. Napoli, G. Curcuruto and G. Ruberto, Biochem. Syst. Ecol., 38, 659 (2010); https://doi.org/10.1016/j.bse.2010.04.001.

34. M. Naggar and K. Iharchine, In XIVeme Congr. For. Mond., pp. 7-11 (2015).

35. R.P. Adams, Identification of Essential Oil Components by Gas Chromatography/Mass Spectrometry, Allured Pub Corp, edn 4 (2007).

36. A. Kumar, S. Kumari N and D. Bhargavan, Asian J. Pharm. Clin. Res., 5, 146 (2012).

37. P.J. Hidalgo, J.L. Ubera, M.T. Tena and M. Valcárcel, J. Agric. Food Chem., 46, 2624 (1998); https://doi.org/10.1021/jf970974j.

38. A. Tawfeeq, A. Culham, F. Davis and M. Reeves, Ind. Crops Prod., 88, 17 (2016); https://doi.org/10.1016/j.indcrop.2016.03.026.

39. A. Khia, M. Ghanmi, B. Satrani, A. Aafi, M. Aberchane, B. Quaboul, A. Chaouch, N. Amusant and Z. Charrouf, Phytotherapie, 12, 341 (2014); https://doi.org/10.1007/s10298-014-0895-x.

40. L. Boutabia, S. Telailia, I. Boughetof, F. Ghenadil and A. Chefrour, Bull. Soc. R. Sci. Liege, 85, 174 (2016).

41. F. Varela, P. Navarrete, R. Cristobal, M. Fanlo, R. Melero, J.A. Sotomayor, M.J. Jordán, P. Cabot, D. Sánchez de Ron, R. Calvo and A. Cases, In: Int. Med. Aromat. Plants Conf. Culin. Herbs 826, pp. 167-174 (2007).

42. S. Santoyo, S. Cavero, L. Jaime, E. Ibanez, F.J. Senorans and G. Reglero, J. Food Prot., 68, 790 (2005); https://doi.org/10.4315/0362-028X-68.4.790.

43. M. Jalali-Heravi, R.S. Moazeni and H. Sereshti, J. Chromatogr. A, 1218, 2569 (2011); https://doi.org/10.1016/j.chroma.2011.02.048.

44. A. Ait-ouazzou, S. Lorán, M. Bakkali, A. Laglaoui, C. Rota, A. Herrera, R. Pagán and P. Conchello, J. Sci. Food Agric., 91, 2643 (2011); https://doi.org/10.1002/jsfa.4505.

45. L. El-Ghadraoui, D. Essakhi and M. Benjelloun, Int. J. Sci. Eng. Res., 6, 166 (2015).

46. Y. Zaouali, T. Bouzaine and M. Boussaid, Food Chem. Toxicol., 48, 3144 (2010); https://doi.org/10.1016/j.fct.2010.08.010.

47. G. Beretta, R. Artali, R.M. Facino and F. Gelmini, J. Pharm. Biomed. Anal., 55, 1255 (2011); https://doi.org/10.1016/j.jpba.2011.03.026.

48. A. Raskovic, I. Milanovic, N. Pavlovic, T. Cebovic, S. Vukmirovic and M. Mikov, BMC Complement. Altern. Med., 14, 225 (2014); https://doi.org/10.1186/1472-6882-14-225. 